HORTSCIENCE 27(1):18-19. 1992.

\section{Effect of Ovule Damage on Fruit Development in Three Apple Cultivars}

John T.A. Proctor and Ido Schechter

Department of Horticultural Science, University of Guelph, Guelph, Ont. NIG 2W1 Canada

Additional index words. fruit deformity, Malus domestica

Abstract. 'McIntosh', 'Delicious', and 'Idared' apple (Malus domestica Borkh.) fruitlet ovaries were artificially damaged with a needle four times after full bloom to assess effects of such damage on fruit growth and development. The damage induced fruit drop, reduced fruit weight, and increased the incidence of fruit deformity, but had no effect on fruit length : diameter ratio. Fruit fresh weight and deformity were correlated with seed per fruit at harvest.

Deformity of apples is an economically important problem in some years, particularly in northern apple-producing areas of North America (Proctor and Lougheed, 1980; Wilde et al., 1984). The cause of the deformed fruit is not known, but fluctuating temperatures during cold acclimation and/or low-temperature injury to young primordial tissue in developing flower buds, or seeds in developing fruits, are suspected (Proctor and Lougheed, 1980; Wilde et al., 1984). Spring frosts can result in flattening at the calyx end of apples (Simons and Lott, 1963). Similarly timed frost damage in pears (Pyrus communis L.; cv. Conference) caused neck thickening or fruit elongation (Modlibowska, 1961). Simulated frost injury to pear ovaries increased fruit deformity, reduced fruit weight, and increased fruit drop in 'Bartlett', 'Bosc', and 'Comice' (Strang et al., 1980).

Our investigation was undertaken to determine the effect of ovule damage imposed on three apple cultivars at various times after bloom on seed count, fruit deformity, and fresh weight.

Mature bearing trees on M.26 East Malling Long Ashton (EMLA) rootstock growing in Fox sandy loam (Typic Hapludalf) at the Cambridge Research Station, Univ. of Guelph, were used in this study. On each of four successive treatment dates, early and late June and early and mid-July 1989 (Figs. 1 and 3), five trees from each of 'Idared', 'Delicious', and 'McIntosh' were selected at random. The full bloom and harvest dates for 'Idared', 'Delicious', arid 'McIntosh' were

Received for publication 15 Feb. 1991. Accepted for publication 26 Aug. 1991. This research was supported in part by the Ontario Ministry of $\mathrm{Ag}$ riculture and Food and by Operating Grant no. A6697 of the Natural Sciences and Engineering Research Council of Canada held by J.T.A.P. Dean Louttit is thanked for valuable technical assistance. The cost of publishing this paper was defrayed in part by the payment of page charges. Under postal regulations, this paper therefore must be hereby marked advertisement solely to indicate this fact,
22 May and 10 Oct., 21 May and 10 Oct., 19 May and 26 Sept., respectively. On each treatment date two representative branches were selected from each tree and 10 flower clusters on each limb were thinned to one fruit to promote maximum fruit set (Westwood and Bjornstad, 1974). On each treatment date, a needle was inserted through the calyx end of each developing fruit to damage the placenta and destroy developing ovules (Abbott, 1959; Strang et al., 1980) on the treated branch. The flower clusters on the other branch remained as a control. At har- vest, the remaining fruit on these two branches were collected and each apple was rated for deformity on a scale of 1 (no deformity) to 5 (severe deformity) (Proctor and Lougheed 1980). Fruit weight, its length : diameter ratio (L : D), and seed count were recorded.

Data were subjected to analysis of variance (ANOVA) with the source of variation including the main effects of cultivar, date, and treatment and their interaction terms (cultivar $\mathrm{x}$ date, cultivar $\mathrm{x}$ treatment, date $\mathrm{x}$ treatment, cultivar $\mathrm{x}$ date $\mathrm{x}$ treatment). The nonsignificant interaction terms were pooled with the error sums of square. The variable means were separated using the LSMEANS option of the Statistical Analysis System program package (SAS Institute, Cary, N.C.), which accounts for unequal samples.

Seed count. 'McIntosh' in general had more seeds than 'Idared', and 'Delicious' had the least (Fig. 1). The treatments always reduced the number of seeds but did not eliminate them. Although there were temporal differences in seed number due to treatment, the variation likely was due to the crudeness of the treatment application. Nevertheless, this variation and inconsistency may be similar to those observed in developing fruits after spring freezes (Modlibowska, 1975).

Fruit deformity. The injuries increased fruit deformity in all cultivars (Table 1). Typi-

Table 1. Effect of mechanical damage to the ovule of three apple cultivars at various times after full bloom on fruit deformity, fresh weight, and length : diameter ratio at harvest.

\begin{tabular}{llcc}
\hline \hline & & \multicolumn{2}{c}{ Mean at all treatment dates } \\
\cline { 3 - 4 } Variable & Cultivar & Not damaged & Damaged \\
\hline Fruit deformity & McIntosh & 1.0 & $1.6^{*}$ \\
& Delicious & 1.0 & $1.4^{*}$ \\
& Idared & 1.6 & $2.5^{*}$ \\
Fruit fresh wt $(\mathrm{g})$ & Mclntosh & 164 & $135^{*}$ \\
& Delicious & 127 & $106^{*}$ \\
& Idared & 121 & $99^{*}$ \\
\hline
\end{tabular}

aDeformity index of 1 (no deformily), to 5 (extreme deformity), illustrated in Proctor and Lougheed (1980).

${ }^{*}$ Means significantly different at $P=0.05$.

Table 2. Effect of application time of mechanical damage to ovules on percentages fruit drop determined at harvest in three apple cultivars in 1989.

\begin{tabular}{|c|c|c|c|}
\hline \multirow[b]{2}{*}{ Cultivar } & \multirow{2}{*}{$\begin{array}{l}\text { Date of } \\
\text { treatment (days from } \\
\text { full bloom) }\end{array}$} & \multicolumn{2}{|c|}{$\begin{array}{l}\text { Mean fruit drop at harvest time } \\
(\%)\end{array}$} \\
\hline & & Not damaged & Damaged \\
\hline McIntosh & $\begin{array}{l}17 \\
33 \\
43 \\
54\end{array}$ & $\begin{aligned} 39 & \pm 16^{y} \\
22 & \pm 11 \\
4 & \pm 4 \\
0 & \pm 0\end{aligned}$ & $\begin{array}{l}68 \pm 11 \\
78 \pm 7 \\
60 \pm 14 \\
48 \pm 26\end{array}$ \\
\hline Delicious & $\begin{array}{l}19 \\
35 \\
45 \\
56\end{array}$ & $\begin{array}{r}45 \pm 13 \\
20 \pm 10 \\
14 \pm 11 \\
4 \pm 4\end{array}$ & $\begin{array}{l}70 \pm 10 \\
53 \pm 23 \\
50 \pm 12 \\
18 \pm 13\end{array}$ \\
\hline Idared & $\begin{array}{l}20 \\
36 \\
46 \\
57\end{array}$ & $\begin{array}{r}23 \pm 13 \\
2 \pm 2 \\
0 \pm 0 \\
6 \pm 4\end{array}$ & $\begin{array}{l}42 \pm 17 \\
34 \pm 14 \\
24 \pm 15 \\
30 \pm 11\end{array}$ \\
\hline
\end{tabular}

${ }^{2}$ Mean \% fruit drop from five branches.

${ }^{y_{S E}}$. 


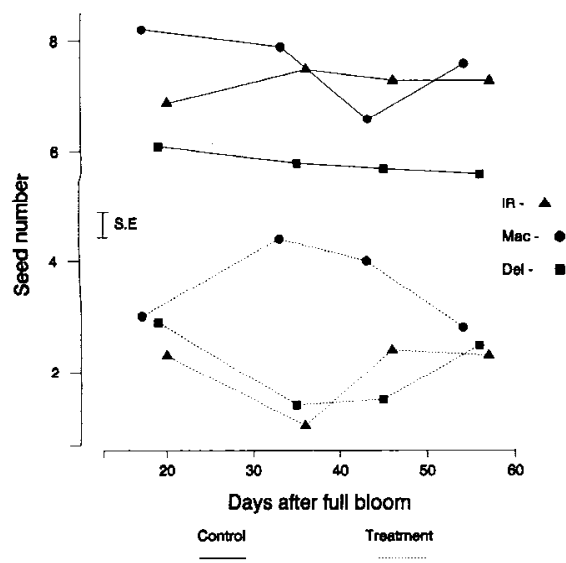

Fig. 1. Seed number per fruit at harvest of apples of IR ('Idared'), Mac ('McIntosh') and Del ('Delicious') that had been artificially damaged at four times after full bloom (Treatment) or not damaged. The vertical line is SE.

Table 3. Correlation of fruit seed number with fruit fresh weight and deformity at harvest.

\begin{tabular}{lccc}
\hline \hline & $\begin{array}{c}\text { Fruit } \\
\text { tested } \\
\text { Cultivar }\end{array}$ & \multicolumn{2}{c}{ Correlation coefficient $(r)^{\mathrm{z}}$} \\
\cline { 3 - 4 } \cline { 4 - 4 } (no.) & Fresh wt & Fruit deformity \\
\hline McIntosh & 44 & 0.29 & -0.54 \\
Delicious & 32 & 0.54 & -0.47 \\
Idared & 44 & 0.58 & -0.62 \\
\hline
\end{tabular}

${ }^{2}$ All $r$ are significant at $P=0.05$.

yFruit deformity index as in Table 1.

cally deformed 'Idared' fruit are illustrated in Fig. 2. 'Idared' was significantly more prone to ovary damage than 'McIntosh' or 'Delicious', and the severity of deformity was consistent across treatment dates (Fig. 3). 'Delicious' fruit did not differ on the first application date from the control fruit (small sample size), but on the remaining dates the deformity rating was higher but not related to treatment date. Treated 'McIntosh' fruit were highly affected, but the deformity rating decreased steadily with time and was not significant on the last date. This difference in response in 'McIntosh' may be due to cultivar and/or related to treatment applications.

Fruit drop. The treatment increased fruit

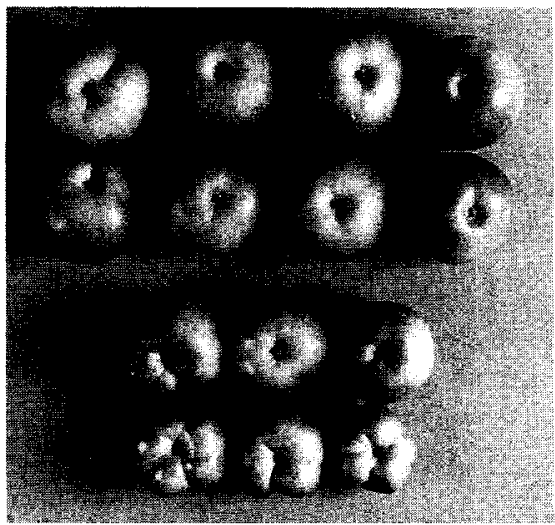

Fig. 2. Control (top two rows) and damaged 'Idared' apples at harvest. Injury leading to the damage was imposed 20 days after full bloom.

drop in all three cultivars (Table 2). The highest percentage fruit drop was generally from the first treatment date. 'McIntosh' was very prone to injury, and even on the last treatment date $48 \%$ of the treated fruit dropped. Abbott (1959) noted that fruit growth depended on seeds only in the early stages of growth (7 weeks after petal fall). Data from this study indicate that drop due to injury to the ovule is cultivar-dependent.

Fruit fresh weight, length : diameter ratio, deformity, and seed number. Ovary damage reduced fruit weight at harvest in all three cultivars (Table 1). Neither treatment nor date effects on fruit $\mathrm{L}$ : D ratio were found (range 0.78-0.92). Both fruit fresh weight and deformity were correlated with fruit seed number at harvest (Table 3). The more seeds per fruit, particularly for 'Delicious' and 'Idared', the larger the fruit; conversely, the fewer the seeds, the more deformed the fruit, especially for 'Idared'.

In conclusion, ovary damage caused by the insertion of a needle, although a somewhat crude simulation of frost damage to the ovules, brings about dramatic effects on fruit growth and development and may be an acceptable way to study the role of seeds in fruit growth, particularly in some cultivars.

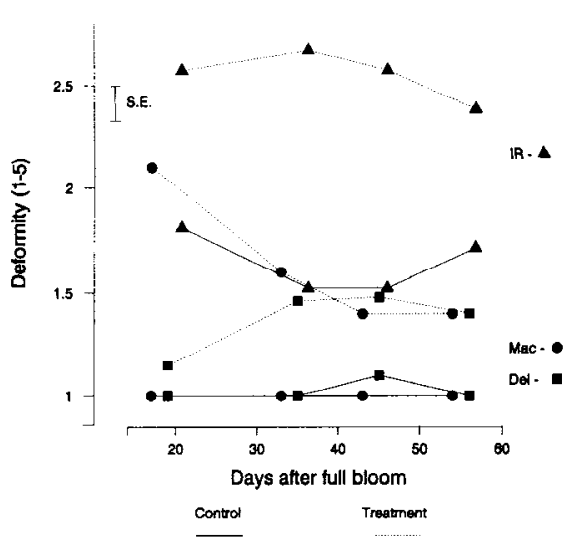

Fig. 3. Fruit deformity $(1=$ no deformity, $5=$ severe deformity) of apples of IR ('Idared'), Mac ('McIntosh') and Del ('Delicious') that had been artificially damaged at four times after full bloom (Treatment) or not damaged. The vertical line is SE.

\section{Literature Cited}

Abbott, D.L. 1959. The effects of seed removal on the growth of apple fruitlets. Annu. Rpt. Long Ashton Res. Sta. 1958. p. 52-56.

Modlibowska, I. 1961. Stimulation of fruit development in frost damaged pears. Rpt. East Malling Res. Sta. for 1960; p. 46-48.

Modlibowska, I. 1975. Effects of frost on crop yield and quality, p. 73-81. In: H.C. Pereira (ed.). Climate and the orchard. Cmwlth. Agr. Bur., Slough, England.

Proctor, J.T.A. and E.C. Lougheed. 1980. A deformity of apples of unknown origin. Can. Plant. Dis. Surv. 60:13-16.

Simons, R.K. and R.V. Lott. 1963. The morphological and anatomical development of apple injured by late spring frost. Proc. Amer. Sot. Hart. Sci. 83:88-100.

Strang, J.G., P.B. Lombard, and M.N. Westwood. 1980. Effect of simulated frost injury on fruit development in three pear cultivars. J. Amer. Sot. Hort. Sci. 105:63-65.

Westwood, M.N. and H.O. Bjomstad. 1974. Fruit set as related to girdling early cluster thinning and pruning of "Anjou" and "Cornice" pear. HortScience 9:342-344.

Wilde, M.H., F.J. McNicholas, and G.D. Blanpied. 1984. Anatomy of grooved apple injury. Can. J. Plant Sci. 64:1015-1017. 